\title{
Porphyria; A Rare Cause of Neurological Symptoms in Cancer Patient
}

\section{Porfiri; Kanser Hastasında Nörolojik Semptomların Nadir Bir Sebebi}

\author{
Ali Alkan ${ }^{1}$, Ebru Karcı' ${ }^{1}$, Betül Yavuz ${ }^{2}$, Abdullah Akdağ ${ }^{1}$, Nalan Akıncı ${ }^{1}$, Arzu Yaşar ${ }^{1}$, Güngör Utkan ${ }^{1}$ \\ ${ }^{1}$ Ankara University School of Medicine, Department of Medical Oncology, Ankara, Turkey \\ ${ }^{2}$ Ankara University School of Medicine, Department of Internal Medicine, Ankara, Turkey
}

Dergiye Ulaşma Tarihi:20.11.2015 Dergiye Kabul Tarihi:08.02.2016 Doi: 10.5505/aot.2016.18209

\section{ÖZET}

Onkoloji pratiğinde nörolojik semptomlar genellikle direkt tümör etkisi veya paraneoplastik sendrom olarak karşımıza çıkmaktadır. Nörolojik semptomlara neden olan nadir hastalıkların tanısı özellikle metastatik kanser hastasında zordur. Burada kırmızı idrar ve nörolojik semptomlarla değerlendirilen bir metastatik akciğer kanseri olgusu sunulmuştur. Metastaz ve paraneoplastik patolojilerin ekartasyonu sonrasında bulgular porfiri tanısı ile ilişkilendirilmiştir. Tecrübemiz porfiri tanı ve tedavi hakkında klinik ipuçları verirken, onkoloji hastasında nörolojik semptomların ayırıcı tanısında tanısal yaklaşımın önemini vurgulamaktadır.

Anahtar kelimeler: Porfiri; Akciğer kanseri; Nörolojik semptomlar

\begin{abstract}
In cancer patient neurological symptoms are mostly due to direct tumor effect or paraneoplastic syndromes. The diagnosis of rare diseases causing neurological symptoms is challenging, especially in a metastatic cancer patient. Here we discussed a metastatic lung cancer patient who presented with red urine and neurological symptoms. After exclusion of metastasis and paraneoplastic pathologies, the findings were associated with the diagnosis of porphyria. While our experience is giving clinical clues about a rare pathology, it also reminds us the importance of work up in the face of neurological symptoms in oncology patients.
\end{abstract}

Key words: Porphyri; Lung Cancer; Neurological symptoms

\section{Introduction}

In oncology practice, especially in metastatic disease, neurological symptoms usually lead the clinician to search brain metastasis or a compressive pathology in vertebral column. Besides common causes, rarely paraneoplastic syndromes may present with progressively deteriorating neurological symptoms. Although paraneoplastic syndromes especially Lambert Eaton syndrome, subacute sensory neuropathy and encephalomyeloneuritis and subacute cerebellar degeneration have been associated with lung cancer, neurological symptoms are usually a consequence of direct metastatic tumor effect (1).

Here we present a nonsmall cell lung cancer patient presenting with insignificant neurological symptoms and a diagnostic process resulting in a diagnosis of porphyria.

\section{Case Presentation}

A 62-year-old male patient, without any comorbidities, presented with dsypnea and hemoptysis. Nodular lesions detected in pulmonary imaging, further conveyed us to a diagnosis of squamous cell carcinoma of the lung with multiple bone metastasis. Patient was hospitalized for palliative intent with a plan of palliative radiotherapy and systemic chemotherapy. In the initial evaluation, patient was apathic and sometimes having difficulty in communication. Intermittent syncope history and progressive mood changes led us for a diagnostic work up. Thyroid, renal and hepatic functions were normal. Cranial imaging was free of either a metastatic lesion or vascular pathology. Behavioral changes and intermittent 
agitation couldn't be explained with an underlying psychiatric pathology and he was treated with a diagnosis of delirium. Due to inconclusive work-up and improvement in neurological symptoms, the patient was treated with palliative radiotherapy for vertebral metastasis and systemic cisplatin- gemcitabin regimen. After 2 courses of chemotherapy, pleural effusion ensued and second line regimen with docetaxel was planned. The patient was treated with drainage of the effusion with thorax tube insertion. During follow up, the patient was treated with numerous antibiotics and palliative medication, especially for emesis and constipation. Chronic dyspepsia was treated with symptomatic medication and intermittent mild abdominal pain was associated with chronic constipation after exclusion of organic pathology with gastroscopy and colonoscopy. During 2 months of follow up, the patient was intermittently sleepy, having speech problems and agitations.

At the end of 2 months of follow up, the patient complained about a 4 days history of reddish urine messing his underwear (Figure-1a/b). Thrombocytopenia due to docetaxel suggested a gross hematuria but it's excluded with urine microscopy. Hemoglobin levels of $8.6 \mathrm{~g} / \mathrm{dl}$ and normal bilirubin, $\mathrm{LDH}$, haptoglobulin, reticulocyte levels excluded hemolysis. Patient was free of a medication, specific food and herbal medicine history that may cause red urine. Nonspecific fluctuating neurological symptoms, intermittent mild diffuse abdominal pain, red urine and increased urobilinogen in urine analysis conveyed the work up for porphyria. Daily porphobilinogen in urine was $4.7 \mathrm{mg}(0-$ $2 \mathrm{mg} / \mathrm{d})$. Coproporphyrin I: $90.2 \mu \mathrm{g} / \mathrm{d}(0-25 \mu \mathrm{g}$ /d), Coproporphyrin III: $80.5 \mu \mathrm{g} / \mathrm{d}(0-75 \mu \mathrm{g} / \mathrm{d})$, total pophyrine: $182.75 \mu \mathrm{g} / \mathrm{d}(0-150 \mu \mathrm{g} / \mathrm{d})$. Symptoms and laboratory results were consistent with the diagnosis of porphyria. Patient medication, especially metoclopramide and antibiotherapy aggravating porphyria was discontinued and red urine improved completely in 1 week (Figure 1c). In the follow up of patient chemo refractory disease progressed and debilitated patient progressively deteriorated and died.

\section{Discussion}

Management of neurological pathology due to metastatic disease is an important part of oncology practice. While direct tumor effect on nervous system is the most encountered cause of symptoms, rarely paraneoplastic syndromes, thromboembolism and electrolyte disorders may cause neurological deficit. Preexisting rare metabolic disorders may be aggravated by tumor itself, chemotherapeutic agents or by supportive medication during management.

Porphyrias are a group of disorders in haem biosynthesis, resulting from genetic enzyme defects in haem synthesis pathway. Seven different types with different enzyme defects have been defined in the pathway. Neuropsychiatric and dermatological problems with different intensity are the clinical results of the accumulating metabolites (2). Accumulation of toxic metabolites and symptoms are usually precipitated. Whereas drugs are the most documented precipitants; infections, malignancy, alcohol and fasting may cause porphyria attack. Besides not exactly defined, Aminolevulinic acid accumulation is hypnotized to be the cause of neurological symptoms. Especially during attacks patient may present with different neurological symptoms such as minor muscle weakness, motor deficits, blood pressure disturbances and dyspepsia. Although dermatological symptomatology may resolve with vesicles, patients may experience severe tissue damage causing digital amputation (3).

Knowledge about porphyrias and cancer is limited in literature. An increased risk for hepatocellular carcinoma in porphyria patients has been reported and screening for primary liver malignancy in pophyric patients has been recommended (4,5). Liver metastasis has been 
documented as a triggering factor of porphyria attacks. In addition to relation with hepatic malignancies, porphyria has been reported as a risk factor for lung cancer in a cohort study from Denmark and Sweden (6).

Management of a cancer patient with a diagnosis of porphyria is difficult. Especially selecting the best effective regimen in potential precipitant chemotherapeutic and palliative medications is challenging. The data about the cytotoxic drug used in porphyric patients is limited and safety data is only a total of experiences in case reports. Taxanes; docetaxel and paclitaxel, cyclophosphamide, busulfan, methotrexate, anastrazole, letrozole, tamoxifen are the porphyrinogenic drugs. Fluorouracil, Doxorubucin, Epirubicin, carbolatin, Capecitabine are drugs that are probably not porphyrinogenic (7). Palliative medications such as 5HT3 antagonists, metoclopramide, steroids, paracetamol, tramadol, fentanil are in the "probably not porphyrinogenic" group. Aprepitant is in the probably porphyrinogenic group (2).
Different experiences with different drugs have been reported in literature. Before chosing drug it must be carefully discussed.

In our patient, management of neurological symptoms caused by a rare disease was challenging. Due to nonspecific findings, age of the patient and possible metastatic or paraneoplastic syndrome postponed the diagnosis. The analysis of the drugs used for detection of the precipitant was inconclusive. Second line regimen docetaxel has been reported to be precipitant in literature but the absence of symptoms during therapy and nearly 2 weeks period between symptoms and therapy decreases the likelihood of it. The ongoing nasocomial pneumonia was thought to be the precipitating factor. While our experience is giving clinical clues about a rare pathology, it also reminds us the importance of work up in the face of neurological symptoms in oncology patients.

\section{Conflict of interest: None}

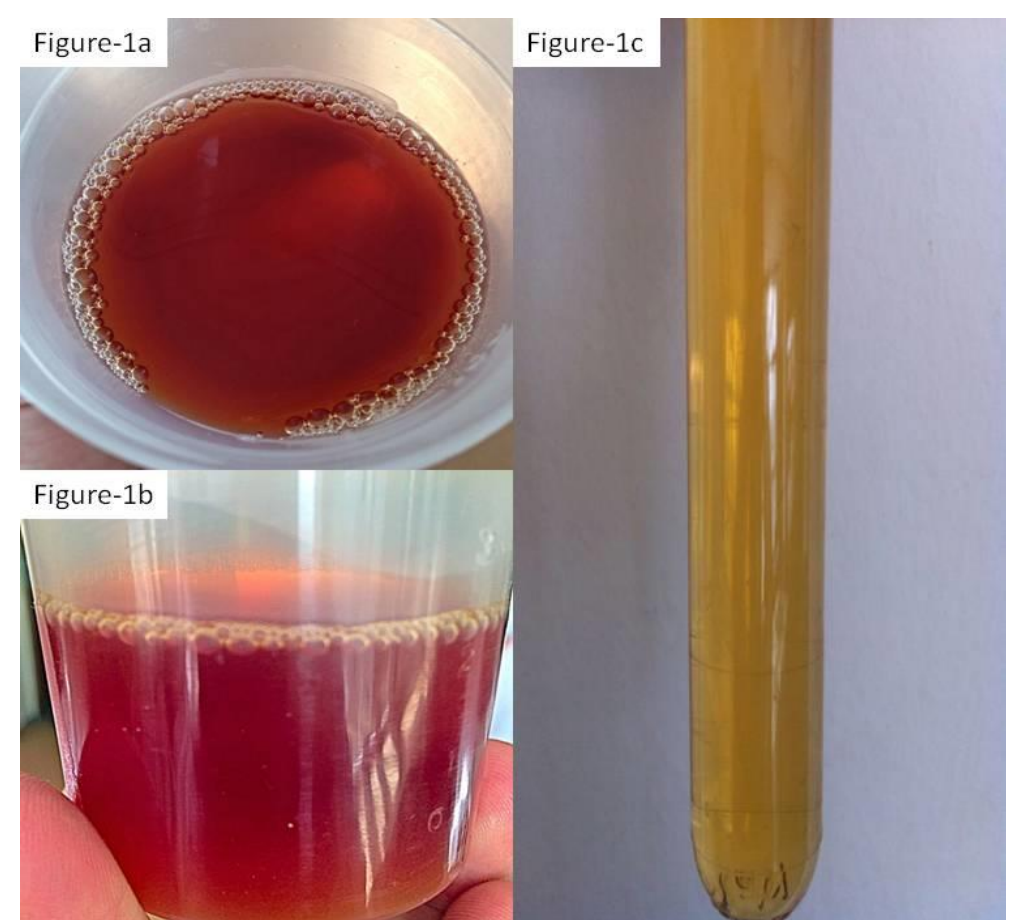

Figure 1: Reddish urine observed during exacerbation(1ab), Normal color urine after resolution of attack of porphyria(1c) 


\section{Referanslar}

1. Dropcho EJ. Neurologic complications of lung cancer. Handbook of clinical neurology. 2014;119:335-61

2. Palmieri C, Vigushin DM, Peters TJ. Managing malignant disease in patients with porphyria. QJM : monthly journal of the Association of Physicians. 2004;97:115-26

3. Balwani M, Desnick RJ. The porphyrias: advances in diagnosis and treatment. Hematology / the Education Program of the American Society of Hematology American Society of Hematology Education Program. 2012;2012:19-27

4. Kaczynski J, Hansson G, Thunell S, Wetterberg L, Wallerstedt S. Erythrocyte porphobilinogen deaminase activity and primary liver cancer. Journal of internal medicine. 1995;237:309-13

5. Innala E, Andersson C. Screening for hepatocellular carcinoma in acute intermittent porphyria: a 15-year follow-up in northern Sweden. Journal of internal medicine. 2011;269:538-45

6. Linet MS, Gridley G, Nyren $\mathrm{O}$ et al. Primary liver cancer, other malignancies, and mortality risks following porphyria: a cohort study in Denmark and Sweden. American journal of epidemiology. 1999;149:1010-5

7. Thiery-Vuillemin A, Chaigneau L, Meaux-Ruault N et al. Anticancer therapy in patients with porphyrias: evidence today. Expert opinion on drug safety. 2008;7:159-65 